\title{
REPRODUCTIVE PHASE DEPEDENT CIRCADIAN VARIATION IN THE PINEAL BIOCHEMICAL CONSTITUENTS OF INDIAN PALM SQUIRREL, FUNAMBULUS PENNANTI
}

\author{
C. HALDAR* and RATNA SARKAR \\ Department of Zoology, Banaras Hindu University, Varanasi-221 005, India
}

(Received: September 9, 1999; accepted: December 17, 1999)

\begin{abstract}
In mammals, pineal gland is intimately concerned with the co-ordination of rhythm physiology. Biochemical characteristics of pineal gland in man and other mammals may provide strong, yet sometimes elusive support for the belief in functional individuality and probable importance of this tiny gland. In seasonal breeding animals, pineal gland function is very much dependent on the reproductive status. Therefore, the aim of this experiment is to note the circadian rhythmicity of different biochemical constituents of pineal gland during active and inactive phases of reproductive cycle of a seasonally breeding rodent, $F$. pennanti. In the present study, pineal biochemical constituents i.e. protein and cholesterol showed higher values during daytime $(1400 \mathrm{~h})$. The plasma melatonin level presented two peaks during active (April; at $1800 \mathrm{~h}$ and $0200 \mathrm{~h}$ ) and inactive (December; at $1400 \mathrm{~h}$ and $0200 \mathrm{~h}$ ) phases of reproductive cycle. The pineal protein, cholesterol and plasma melatonin values in term of basal and peak levels were higher during the reproductive inactive/pineal active phase. Therefore, pineal - also known to have antigonadotropic properties and cholesterol which appears conjugated with pineal serotonin, presented circadian rhythmicity along with the plasma level of melatonin. This rhythmicity noted in present study was dependent on the reproductive and pineal activity status, and might be regulated by the sex steroid receptor present on the pineal gland.
\end{abstract}

Keywords: Pineal gland - protein - cholesterol - melatonin - reproductive phase - day length - rhythmicity - sex steroid receptor

\section{INTRODUCTION}

The pineal gland is involved in the control of various rhythms such as circadian, ultradian and circannual rhythms by entraining the light/dark cycle [1]. The biochemical activities of pineal gland are correlated to the daily pattern of light [2]. Biochemical analysis of pineal gland exhibited the presence of incredible number of compounds attributed distinctive functions. Recently, we have reported that the biochemical constituents such as protein, cholesterol and serotonin can act as markers of pineal gland activity other than melatonin [3].

It has been demonstrated that pineal peptide factors extracted from pineal tissue of various animals either inhibit or stimulate gonadal activities under defined experi-

* Corresponding author; E-mail: chaldar@banaras.ernet.in 
mental conditions. Unfortunately, till date not a single protein/peptide compound specific to pineal gland has yet been identified. Apparently, in all mammalian species histochemical and electron-microscopical investigations have figured the presence of lipid inclusions [2]. Pineal lipids are primarily involved in general metabolism and membrane structure and functions. More than half of this lipid is phospholipid, with most of the remainder consisting of free cholesterol and glycerides [4]. Further, $13 \%-16 \%$ of the total lipid of young rat brain is cholesterol [5]. However, no lipid compounds have been noted to be specific to pineal gland.

The light/dark cycle seems to be the most important factor governing the melatonin synthesis and secretions $[1,6,7]$ which in turn regulate the gonadal function of seasonally breeding animals of temperate and tropical zones $[8,9,10]$. Hence, an attempt was made to study the circadian variation of different pineal biochemical constituents such as protein, cholesterol and plasma melatonin level in a subtropical zone rodent, $F$. pennanti during reproductive active and inactive phases.

\section{MATERIAL AND METHODS}

\section{Collection and maintenance}

The Indian palm squirrel, F. pennanti is a seasonal breeder, arboreal in habitat and partial hibernator. The sexual cycle in male [10] presents a clear biphasic annual testicular cycle characterized by a short period of quiscence with total arrest of spermatogenesis during October-November. On the other hand, increase in testicular activity is noted from March followed by active phase during April-June. Thirty-five adult male squirrels (body weight $100 \mathrm{~g} \pm 10 \mathrm{~g}$ ) were obtained from the local suppliers at the vicinity of Varanasi (Long. $83^{\circ}, 1^{\prime}$ East; Lat.: $25^{\circ}, 18^{\prime}$ North) during each phase of reproductive cycle. The squirrels were given access to food consisting of soaked gram seeds (Cicer arietinum) and water ad libitum.

\section{Experimental design}

The experiments were performed during reproductive active phase i.e. April (temperature: $\max .35 .3{ }^{\circ} \mathrm{C}-18.1{ }^{\circ} \mathrm{C}$; humidity: $\max 65.4 \%-\min .27 .4 \%$; day length $1245 \mathrm{~h}$ ) and reproductive inactive phase i.e. November (temperature: $\max .18 .0^{\circ} \mathrm{C}-$ min. $5.8{ }^{\circ} \mathrm{C}$; humidity: max. $45.0 \%$ - min. $24.0 \%$; day length $1030 \mathrm{~h}$ ). After a week of acclimatisation five squirrels were sacrificed at every 4 hours interval by decapitation and body weight was noted.

\section{Biochemical assay}

Protein was estimated by homogenising the pineal gland in $0.9 \% \mathrm{NaCl}$ following the method of Lowry et al. [11], total colesterol was estimated by homogenising the 
pineal gland in acetone : ether mixture (3:1) following the method of Sacket [12]. The radioimmuno assay of melatonin was performed by the method of Rollag and Niswender [13] using ${ }^{3} \mathrm{H}$ melatonin (Amersham, USA) and antibody (Guild antiserasheep antimelatonin Batch no. G/S/704-8483, Surrey, Guilford, UK). Data were expressed as means \pm standard error of means (SEM).

\section{RESULT}

\section{Variation in pineal gland weight}

During reproductive active phase the highest value of pineal gland weight noted at $0200 \mathrm{~h}(1.4 \pm 0.1 \mathrm{mg} / 100 \mathrm{~g}$ body wt. $)$ while, lowest value was noted at $1000 \mathrm{~h}$ $(0.5 \pm 0.05 \mathrm{mg} / 100 \mathrm{~g}$ body wt.) (Figs 1,2$)$. During reproductive inactive phase the highest value of pineal gland weight noted at $0200 \mathrm{~h}(2.3 \pm 0.1 \mathrm{mg} / 100 \mathrm{~g}$ body wt. $)$ while, lowest value was noted at $1000 \mathrm{~h}(0.5 \pm 0.05 \mathrm{mg} / 100 \mathrm{~g}$ body wt.).

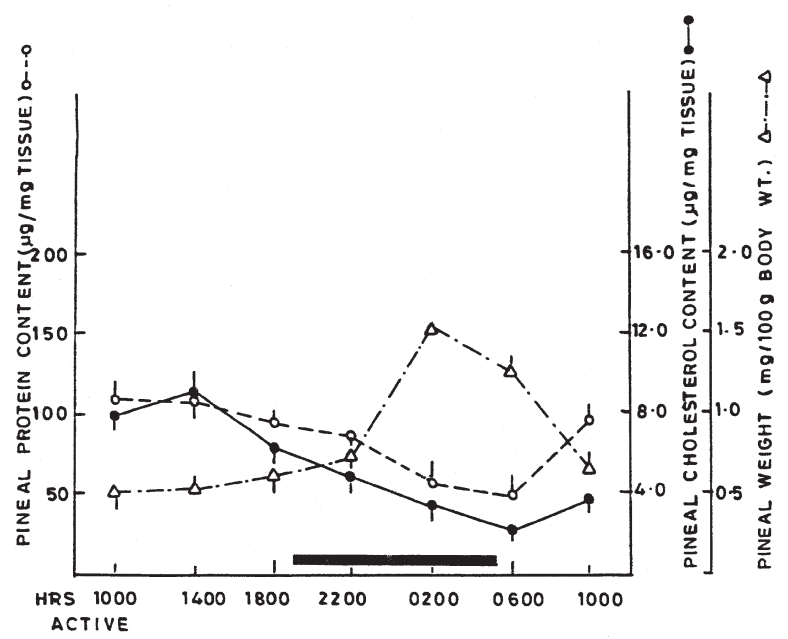

Fig. 1. Circadian variation in pineal weight, pineal protein and cholesterol content of $F$. pennani during reproductive active phase; April (Means \pm SEM)

\section{Variation in pineal protein}

During reproductive active phase the highest value of protein content was observed at $1400 \mathrm{~h}(110 \pm 9.25 \mu \mathrm{g} / \mathrm{mg})$ while, lowest value observed at $0600 \mathrm{~h}(25.5 \pm 5.5$ $\mu \mathrm{g} / \mathrm{mg}$ ). During reproductive inactive phase the highest value was observed at 1400 $\mathrm{h}(262 \pm 15.0 \mu \mathrm{g} / \mathrm{mg})$ while, lowest value was noted at 0200 and $0600 \mathrm{~h}(150.2 \pm$ $\pm 12.5 \mu \mathrm{g} / \mathrm{mg}$ ) (Figs 1, 2). 


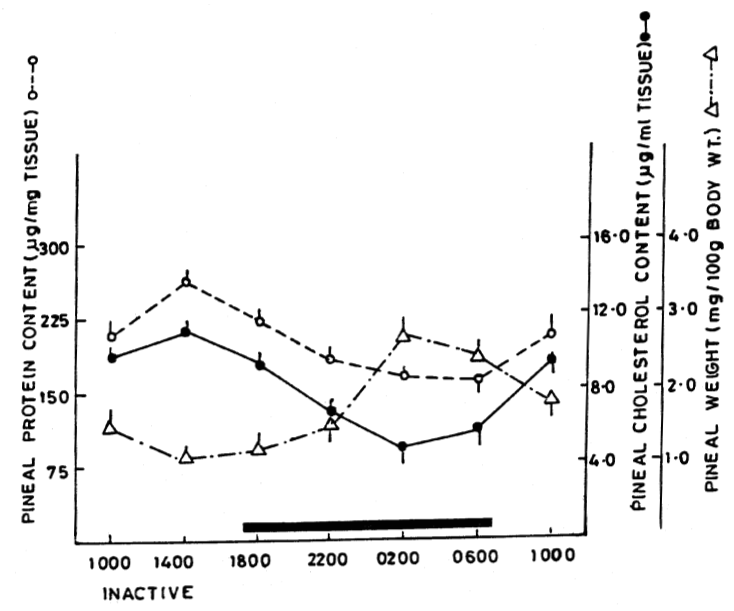

Fig. 2. Circadian variation in pineal weight, pineal protein and cholesterol content of $F$. pennani during reproductive inactive phase; November (Means \pm SEM)

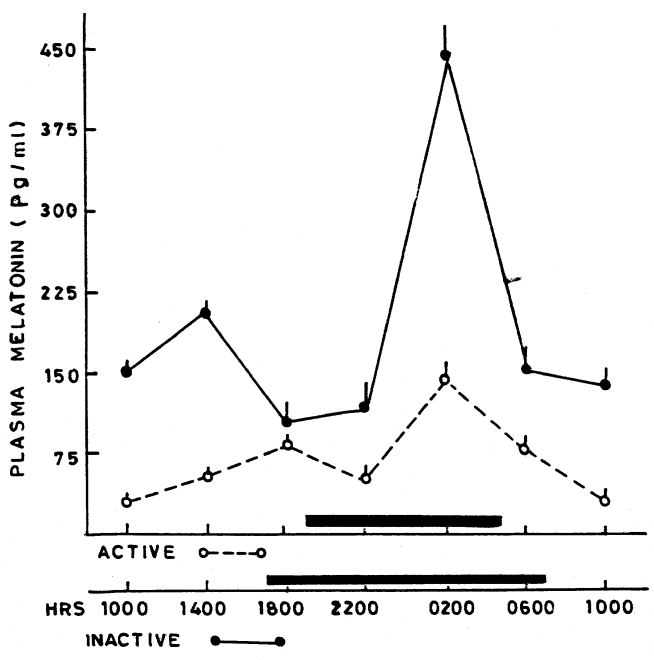

Fig. 3. Circadian variation in plasma melatonin level of $F$. pennani during reproductive active; April and inactive phases; November (Means \pm SEM)

\section{Variation in pineal cholesterol}

The highest value of pineal cholesterol was noted at $1400 \mathrm{~h}(8.33 \pm 0.58 \mu \mathrm{g} / \mathrm{mg}$; $13.99 \pm 0.83 \mu \mathrm{g} / \mathrm{mg}$ ) during reproductive active and inactive phases, respectively, while, lowest values were noted at $0600 \mathrm{~h}$ and $0200 \mathrm{~h}(2.1 \pm 0.5 \mu \mathrm{g} / \mathrm{mg} ; 5.1 \pm 0.5$ $\mu \mathrm{g} / \mathrm{mg}$ ), respectively (Figs 1, 2). 


\section{Variation in plasma melatonin content}

Circadian variation in plasma melatonin levels presented two peak cyclicity (Fig. 3). During reproductive active phase first peak (dusk peak) was observed at $1800 \mathrm{~h}$ $(100 \pm 12.49 \mathrm{pg} / \mathrm{ml})$ while, a second peak (dawn peak) at $0200 \mathrm{~h}(64.16 \pm 9.99$ $\mathrm{pg} / \mathrm{ml}$ ). During reproductive inactive phase there was a preshifting of dusk peak. It appeared at $1400 \mathrm{~h}(255 \pm 22.5 \mathrm{pg} / \mathrm{ml})$ and the dawn peak appeared at $0200 \mathrm{~h}$ $(472 \pm 85 \mathrm{pg} / \mathrm{ml})$.

\section{DISCUSSION}

Till date, biochemical constituents of pineal gland remain to be defined with a functional status. Partially, it has been explained by Quay [2] in his book "Pineal Chemistry in cellular and physiology mechanisms" but only pineal protein/peptide has received small attention [14]. The amount of cholesterol reported here and elsewhere still needs a proper functional definition. In the present experiment the day/night variation in the biochemical constituent was noted during two different activity phases in the squirrel. The peak values for protein and cholesterol were observed in the afternoon $(1400 \mathrm{~h})$ and lowest values after the onset of darkness (i.e. 0200-0600 h). Our results showed a similarity in between the rhythm of protein and cholesterol. It could be that the higher protein content at $1400 \mathrm{~h}$ is due to the synthesis of n-acetyl transferase (NAT), which is needed to act on the substrate serotonin. However, it is difficult to make any generalized statement regarding the pineal specificity for protein content. This protein could be the unknown pineal antigonadotropic peptide or the enzyme involved in melatonin synthesis. Since, lipid is involved with serotonin synthesis/release [2] and hence may be for this reason a high level of cholesterol was noted at $1400 \mathrm{~h}$ along with the protein. It may therefore be suggested that the environmental light and temperature affect the level of these two pineal biochemical constituents in this seasonal breeder. Various reports suggest that continuous light causes changes in pineal RNA though continuous darkness has no significant effect on DNA, RNA or protein [15]. However, in adult rabbit continuous darkness abolishes day/night difference in concentration of total protein, tryptophan containing protein and relative fluorescence of tryptophan containing protein [16].

The plasma MEL content presented two peaks cyclicity during both the phases of reproductive cycle. During reproductive inactive phase the first peak was shifted from $1400 \mathrm{~h}$ to $1800 \mathrm{~h}$ while, second peak remained at $0200 \mathrm{~h}$. However, the basal and peak levels in MEL concentration are higher in reproductive inactive phase as the pineal gland was in a functionally active phase. The light/dark cycle seems to be the most important factor, governing the MEL synthesis/secretion. Several studies have demonstrated that chronic exposure of light during night time depleted the MEL level [17] or continuous light exposure during the normal dark period, a moderately low MEL level persisted [18]. In F. pennanti, during the month of December, short day length $(1030 \mathrm{~h})$ might have caused the noctural rise in plasma melatonin level 
whereas, during April, long day length $(1245 \mathrm{~h})$ could not elevate the nocturnal plasma melatonin level to the extent noted at December. The duration of the MEL peak may be the signal by which pineal gland apprises the animal of the photoperiodic environment to which it is exposed [19]. Several reports have shown that the endocrine physiology of mammals is adjusted accordingly to the photoperiod or the duration of infused melatonin to which they are exposed [20]; if animals are pinealectomized, photoperiodic information no longer has an impact on the endocrine system. Thus, it may be suggested that the transduction of a neural message into a hormonal envoy in the pineal gland provide a critical link between the animal and its external environment. Further, other environmental factors like temperature and humidity are found to be effective, by influencing the pineal gland activity. It may be suggested that low temperature $\left(\max .18{ }^{\circ} \mathrm{C} ; \min .5 .8{ }^{\circ} \mathrm{C}\right)$ and moderate humidity $(45 \%)$ and high temperature $\left(\max .35 .3{ }^{\circ} \mathrm{C}\right.$; min. $\left.18.1{ }^{\circ} \mathrm{C}\right)$ high humidity $(65 \%)$ could be responsible for high plasma melatonin and low plasma melatonin levels, respectively.

It has been reported that in rats, exposed for $24 \mathrm{~h}$ to an ambient temperature of $33{ }^{\circ} \mathrm{C}$, there was a $17 \%$ decrease in the daytime hydroxyindole-o-methyl transferase activity (HIOMT) [21]. Moreover, NAT activity has been reported to decrease after a similar exposure to high temperature, both during day and night time [22]. In suckling rats, NAT activity was diminished when they were exposed to high $\left(34^{\circ} \mathrm{C}\right)$ or low $\left(7^{\circ} \mathrm{C}\right)$ temperature compared to controls $\left(22^{\circ} \mathrm{C}\right)$. Other reports regarding the effects of light and temperature on the pineal serotonin, HIOMT and NAT content suggested that there could be a "dual mechanism controlling the pineal function in suckling rats". This is because of sensitivity of NAT to temperature and serotonin to environmental illumination [23]. These results reinforce the hypothesis of the probable temperature depedence of seasonal day length variation in pineal melatonin level.

It is therefore, clear that the constituents studied in the pineal gland are definitely active as they show a perfect circadian rhythmic pattern. The low level of protein and cholesterol during dark phase may signify their role in active utilisation as substrate/ carrier of energy etc. for melatonin synthesis/ release during this phase. Rhythmicity of pineal constituents was noted to be dependent on the reproductive and pineal activity status, may be due to the circulatory steroid level and presence of sex steroid receptor on pineal gland [24].

\section{ACKNOWLEDGEMENT}

Authors thank to University Grants Commission, New Delhi, India for the financial support. 


\section{REFERENCES}

1. Reiter, R. J. (1993) The melatonin rhythm: both a clock and a calendar. Experienta 49, 654-664.

2. Quay, W. B. (1974) Soluble proteins and peptides. In: Pineal chemistry in cellular and physiological mechanisms. Charles C. Thomas, Springfield, pp. 290-313.

3. Sarkar, R., Haldar, C. (1997) 5-methoxyondoles (MEL, 5-MT and 5-MTP) induced biochemical changes in the pineal gland of Indian palm squirrel, Funambulus pennanti. Biogenic Amines 13, $153-159$.

4. Quay, W. B. (1981) General biochemistry of pineal gland of mammals. In: Reiter, R. J. (eds) The pineal gland, Anatomy and Biochemistry. CRC Press, 173-198.

5. Basinska, J., Sastry, P. S., Stancer, H. C. (1969) Lipid composition of human, bovine and sheep pineal glands. J. Neurochem. 16, 707-714.

6. Ebadi, M., Samejima, M., Pfeiffer, R. F. (1993) Pineal gland in synchronizing and refining physiological events. NIPS. 8, 30-33.

7. Haldar, C., Ghosh, M. (1995) Pineal-gonadal relationship of the Indian spotted owlet, Athene brama. J. Reprod. Biol. Comp. Endocrinol. 7, 8-18.

8. Newman, R. E., Folder, A., Maxwell, C. A., Baker, P., Wynn, P. C. (1990) Elevated day time melatonin levels and seasonality in the fallow deer. Proc. V. Coll. EPSG, Guildford, U.K. Abs. No. 1.

9. Haldar, C., Srivastava, M. (1989) Effect of pinealectomy on photoperiodic gonadal response of Indian palm squirrel, F. pennanti. Canad. J. Zool. 65, 833-836.

10. Haldar, C., Saxena, N. (1988) Tropical environmental impact on reproduction: Role of pineal gland. Threat. Hab. 1, 307-320.

11. Lowry, O. H., Rosenbrough, N. J., Farr, A. L., Randall, R. J. (1951) Protein measurements with the Folin phenol reagent. J. Biol. Chem. 193, 265-275.

12. Sacket, G. E. (1925) Lipids. In: Varley, H. (eds.) Practical clinical biochemistry. Willium Heinemann Medical Book Ltd., 309.

13. Rollag, M. D., Niswender, G. D. (1976) Radioimmunoassay of serum concentration of melatonin in sheep exposed to different lighting regimens. Endocrinology 98, 482-489.

14. Benson, B., Ebels, I., Hruby, V. L. (1990) Isolation and structure elucidation of bovine pineal arginine vasopressin: arginine vasotocin not identified. Int. J. Peptide Protein. 36, 109-121.

15. Nir, I., Hirschmann, N., Mishkinsky, J., Sulman, F. G. (1969) The effect of light and darkness on nuclic acid and protein metabolism of the pineal gland. Life Sci. 8, 279.

16. Smith, A. R. (1972) Condition influencing serotonin and tryptophan metabolism in the Epiphysis cerebi of the rabbit; a fluorescence histochemical, microchemical and electrophoretic study. Thesis Purmerend, The Netherlands, Nooy's Druk Kerij, 1.

17. Reiter R. J., Richardson, B. A., Matthews, S. A., Lane, S. C., Ferguson, B. N. (1983) Rhythms in immunoreactive melatonin in the retina and harderian gland of rats: persistence after pinealectomy. Life Sci. 32, 1229-1236.

18. Panke, E. S., Rollag, M. D., Reiter, R. J. (1979) Pineal melatonin concentrations in the syrian hamster. Endocrinology 104, 194-197.

19. Tamarkin, L., Baird, C. J., Almeida, O. F. X. (1985) Melatonin: a coordinating signal for mammalian reproduction. Science 277, 714-720.

20. Carter, D. S., Goldman, B. D. (1983) Antigonadal effects of timed melatonin infusions in pinealectomized male Djungarian hamsters (Phodopus sungorus). Duration is the critical parameter. Endocrinology 113, 1261-1267.

21. Nir, I., Hirschmann, N., Sulman, F. G. (1975) The effects of heat on rat pineal hydroxyindole-omethyl-transferase activity. Experientia 31, 867-868.

22. Nir, I., Hirshmann, N. (1978) Pineal N-acetyl transferase depression in rat exposed to heat. Experientia 34, 1645-1646.

23. Klein, D. C., Weller, J. (1972) Rapid light induced decrease in pineal serotonin N-acetyltransferase activity. Science 177, 532.

24. Haldar, C., Gupta, D. (1990) Sex and age dependent nature of the cytoplasmic $5 \alpha$-dihydrotestosterone (DHT) binding site/receptor in bovine pineal gland. J. Pineal Res. 8, 289-295. 
